University of Nebraska - Lincoln

DigitalCommons@University of Nebraska - Lincoln

April 2008

\title{
Complete nucleotide sequence of a maize chlorotic mottle virus isolate from Nebraska
}

Drake Stenger

USDA-ARS

Roy C. French

University of Nebraska-Lincoln, rfrench2@unl.edu

Follow this and additional works at: https://digitalcommons.unl.edu/plantpathpapers

Part of the Plant Pathology Commons

Stenger, Drake and French, Roy C., "Complete nucleotide sequence of a maize chlorotic mottle virus isolate from Nebraska" (2008). Papers in Plant Pathology. 107.

https://digitalcommons.unl.edu/plantpathpapers/107

This Article is brought to you for free and open access by the Plant Pathology Department at DigitalCommons@University of Nebraska - Lincoln. It has been accepted for inclusion in Papers in Plant Pathology by an authorized administrator of DigitalCommons@University of Nebraska - Lincoln. 


\title{
Complete nucleotide sequence of a maize chlorotic mottle virus isolate from Nebraska
}

\author{
Drake C. Stenger $\cdot$ Roy French
}

Received: 14 January 2008/ Accepted: 18 February 2008/Published online: 26 March 2008

\begin{abstract}
The complete genome of a maize chlorotic mottle virus isolate from Nebraska (MCMV-NE) was cloned and sequenced. The MCMV-NE genome consists of 4,436 nucleotides and shares 99.5 nucleotide sequence identity with an MCMV isolate from Kansas (MCMV-KS). Of 22 polymorphic sites, most resulted from transition with a clear bias for $\mathrm{U}$ to $\mathrm{C}$ and $\mathrm{C}$ to $\mathrm{U}$ substitutions. The MCMV-NE genome was assembled into a single plasmid insert and used as a template to transcribe RNA in vitro. As RNA transcribed from the cloned MCMV-NE genome was infectious to maize plants, sequence differences between MCMV-NE and MCMV-KS are most likely neutral with respect to pathogenicity and virulence.
\end{abstract}

\section{Introduction}

Maize chlorotic mottle virus (MCMV) is a small, plussense single stranded RNA virus of the genus Machlomovirus, family Tombusviridae. MCMV was originally identified in Kansas, USA, associated with corn lethal necrosis disease (CLND) [4, 9] resulting from synergistic interaction of MCMV and one of several maize-infecting potyviruses in mixed infections [2]. The genome of an

D. C. Stenger · R. French

USDA-ARS and Department of Plant Pathology,

University of Nebraska, Lincoln, NE 68583, USA

Present Address:

D. C. Stenger $(\square)$

USDA-ARS, 9611 S. Riverbend Ave.,

Parlier, CA 93648, USA

e-mail: drake.stenger@ars.usda.gov isolate of MCMV from Kansas (MCMV-KS) has been completely sequenced [5], used in synergism assays to reproduce CLND [6], and cloned as a full-length cDNA insert from which infectious RNA may be transcribed in vitro [7]. However, genome properties of the MCMV isolate from Nebraska (MCMV-NE) used in disease synergism assays $[2,8]$ and the relationship of this isolate to the well characterized MCMV-KS isolate has not been fully established. Here, we report the complete nucleotide sequence of MCMV-NE, compare the sequence of MCMV-NE with that of MCMV-KS, and describe construction of a full-length MCMV-NE clone serving as template for in vitro transcription of infectious RNA.

\section{Provenance of virus material}

MCMV-NE was originally isolated from infected maize plants grown in NE, USA [2]. Following nearly 20 years in $4^{\circ} \mathrm{C}$ storage as dried infected leaves, the isolate was recovered by sap inoculation of maize inbred line SDp2 seedlings. Inoculated SDp2 plants subsequently developed mild systemic chlorotic mottling symptoms typical of MCMV infection. The virus isolate was verified as MCMV previously [8] using a commercially available ELISA kit (Agdia, Elkhart, IN), by sequencing of cloned reverse transcriptase-polymerase chain reaction (RT-PCR) products containing a 673-nt region of the coat protein (CP) coding region, and by demonstrating its ability to interact synergistically with wheat streak mosaic virus (WSMV) to induce CLND in mixed infections.

MCMV-NE virions were purified [3] from systemically infected SDp2 leaves 14 days post-inoculation. MCMVNE genomic RNA extracted from purified virions consisted of a single RNA molecule of $\sim 4.4 \mathrm{~kb}$ and was used as 
template for reverse transcription with a complementarysense primer based on the complete sequence (GenBank Accession NC-003627) [5] of MCMV-KS and annealing to the 20 terminal nucleotides of the viral RNA $3^{\prime}$-end. Second-strand synthesis was accomplished using RNaseH/ DNA polymerase I, and the ends of the double-stranded DNA product were made blunt-ended by treatment with $\mathrm{T} 4$ DNA polymerase. Enzymes and reaction conditions used for cDNA synthesis were as described for the Riboclone kit by the manufacturer (Promega, Madison, WI). To facilitate cloning, blunt-ended dsDNA was treated with Taq polymerase in the presence of dATP for $30 \mathrm{~min}$ at $68^{\circ} \mathrm{C}$, ligated to pGEM-Teasy (Promega, Madison, WI), and subsequently used to transform Escherichia coli JM109 competent cells.

Cloned MCMV-NE cDNA inserts were crudely mapped to relative positions on the MCMV-NE genome by aligning restriction endonuclease maps. Insert termini were sequenced using universal sequencing primers corresponding to vector sequences flanking the inserts. Internal sequence of each insert was obtained in both directions using multiple sequencing primers based on the MCMVKS sequence. Sequences of each insert were compiled using DNA Sequencher 4.1 (Gene Codes, Ann Arbor, MI, USA). Sequences from multiple inserts were assembled into a single contig to generate a consensus sequence of the MCMV-NE genome in which each nucleotide position called was based on sequences derived from a minimum of three independent clones. The resulting consensus sequence was found to be co-terminal with the MCMV-KS sequence at the $3^{\prime}$-end but lacked 9 nts of $5^{\prime}$-terminal sequence relative to MCMV-KS. The remaining 5 '-terminal sequence of MCMV-NE was determined from cDNA clones generated using the $5^{\prime}$ RACE kit as described by the manufacturer (Invitrogen).

\section{Sequence properties}

The complete nucleotide sequence of MCMV-NE RNA was 4,436 nts in length and appears in GenBank as Accession EU358605. Figure 1 depicts the genome map of MCMV-NE, which is identical to that of MCMV-KS with respect to nucleotide coordinates of start, stop, and readthrough codons for open reading frames (ORFs) p32, p50, p111 (read-through of p50), p7, p31 (read-through of p7), and CP. Overall, the two MCMV complete genome sequences were very closely related, sharing 99.5\% nucleotide sequence identity. This high degree of sequence identity between MCMV-NE and MCMV-KS suggests that the two virus isolates share a very recent common ancestor. This contention is supported by the observation that CP sequences of MCMV from Thailand (AM490791,

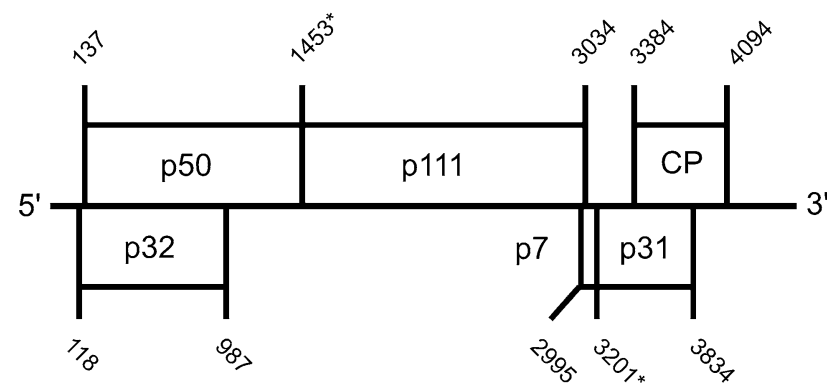

Fig. 1 Genome map of maize chlorotic mottle virus isolate from NE, USA (MCMV-NE). Open reading frames are indicated by boxes; nucleotide coordinates of start and stop positions are indicated. Asterisks denote amber stop codons read through to produce p111 and p31

AM490792, AM490793, and AY587605) differ from MCMV-KS and MCMV-NE by $3.2-4.2 \%$.

MCMV-NE differed in sequence from MCMV-KS at a total of 22 nucleotide positions (Table 1). Twenty polymorphic sites occurred within coding regions (Table 1). Seven polymorphic sites affected two overlapping ORFs in different reading frames. Adjacent substitutions at nucleotides 488 and 489 altered the same codon in each of the two overlapping reading frames. Nonsynonymous codon changes were due to polymorphism at eight nucleotide positions, resulting in a total of nine amino acid substitutions in the encoded proteins. The remaining 16 codon changes at 16 polymorphic sites were synonymous and did not affect encoded amino acid sequences. Of the two polymorphic sites within the $3^{\prime}$-nontranslated region $\left(3^{\prime}\right.$ NTR), one was due to the insertion/deletion of a single nucleotide at position 4,406, accounting for the only gap in the alignment of the two MCMV genomic sequences. The two 5'-NTRs were identical.

Most polymorphic sites were due to transition (18/22), with a clear bias for $\mathrm{U}-\mathrm{C}$ and $\mathrm{C}-\mathrm{U}$ substitutions. Only three polymorphic sites were due to transversion and were too infrequent to assess potential bias of a specific transversion over others. That most nucleotide substitutions among MCMV-KS and MCMV-NE (15/22) were C-U or U-C transitions suggests bias in RNA-dependent RNA polymerase error during replication. A similar trend was observed for two additional viruses of the family Tombusviridae, based on sequences available in GenBank: $\mathrm{C}-\mathrm{U}$ and $\mathrm{U}-\mathrm{C}$ accounted for $54 \%$ of all pairwise substitutions for both carnation mottle virus (3,558/6,535 among $12 \mathrm{CP}$ sequences with a mean pairwise difference of $8.5 \%$ ) and melon necrotic spot virus $(6,341 / 11,742$ among $16 \mathrm{CP}$ sequences with a mean pairwise difference of $8.4 \%$ ).

To evaluate biological relevance of the consensus sequence, the complete genome of MCMV-NE was assembled into a single plasmid for use as an in vitro transcription template to generate RNA inocula. During 
Table 1 Summary of sequence polymorphism between MCMV-KS (GenBank Accession NC_003627) and MCMV-NE (GenBank Accession EU358605)

\begin{tabular}{|c|c|c|c|c|c|}
\hline \multirow[t]{2}{*}{$\begin{array}{l}\text { Nucleotide } \\
\text { coordinate }\end{array}$} & \multicolumn{2}{|c|}{$\begin{array}{l}\text { Nucleotide } \\
\text { polymorphism }\end{array}$} & \multirow{2}{*}{$\begin{array}{l}\text { Open } \\
\text { reading } \\
\text { frame }\end{array}$} & \multicolumn{2}{|c|}{$\begin{array}{l}\text { Amino acid } \\
\text { polymorphism }^{\mathrm{b}}\end{array}$} \\
\hline & $\begin{array}{l}\text { MCMV- } \\
\text { KS }\end{array}$ & $\begin{array}{l}\text { MCMV- } \\
\text { NE }\end{array}$ & & $\begin{array}{l}\text { MCMV- } \\
\text { KS }\end{array}$ & $\begin{array}{l}\text { MCMV- } \\
\text { NE }\end{array}$ \\
\hline \multirow[t]{2}{*}{488} & $\mathrm{U}$ & $\mathrm{C}$ & p32 & $P h e^{c}$ & $\mathrm{Ser}^{\mathrm{c}}$ \\
\hline & & & p50 & $P h e^{c}$ & $\mathrm{His}^{\mathrm{c}}$ \\
\hline \multirow[t]{2}{*}{489} & $\mathrm{U}$ & A & p32 & $P h e^{c}$ & $\mathrm{Ser}^{\mathrm{c}}$ \\
\hline & & & $\mathrm{p} 50$ & $P h e^{c}$ & $\mathrm{His}^{\mathrm{c}}$ \\
\hline \multirow[t]{2}{*}{648} & $\mathrm{C}$ & $\mathrm{U}$ & p32 & - & - \\
\hline & & & $\mathrm{p} 50$ & Ala & Val \\
\hline \multirow[t]{2}{*}{685} & $\mathrm{C}$ & $\mathrm{U}$ & p32 & Tyr & His \\
\hline & & & $\mathrm{p} 50$ & - & - \\
\hline 1,135 & $\mathrm{U}$ & $\mathrm{C}$ & $\mathrm{p} 50$ & - & - \\
\hline 1,166 & $\mathrm{C}$ & $\mathrm{U}$ & $\mathrm{p} 50$ & - & - \\
\hline 1,168 & A & G & $\mathrm{p} 50$ & - & - \\
\hline 1,747 & A & $\mathrm{U}$ & p111 & - & - \\
\hline 2,275 & $\mathrm{U}$ & $\mathrm{C}$ & p111 & - & - \\
\hline 2,337 & $\mathrm{U}$ & $\mathrm{C}$ & p111 & Thr & Pro \\
\hline 2,356 & A & $\mathrm{C}$ & p111 & - & - \\
\hline 2,611 & $\mathrm{U}$ & $\mathrm{C}$ & p111 & - & - \\
\hline 2,755 & $\mathrm{U}$ & $\mathrm{C}$ & p111 & - & - \\
\hline 2,869 & $\mathrm{C}$ & $\mathrm{U}$ & p111 & - & - \\
\hline 2,947 & $\mathrm{C}$ & $\mathrm{U}$ & p111 & - & - \\
\hline \multirow[t]{2}{*}{3,011} & $\mathrm{C}$ & $\mathrm{U}$ & p7 & Thr & Ile \\
\hline & & & p111 & His & Tyr \\
\hline 3,054 & $\mathrm{C}$ & $\mathrm{U}$ & p7 & - & - \\
\hline \multirow[t]{2}{*}{3,389} & G & A & p31 & Arg & Gln \\
\hline & & & $\mathrm{CP}$ & - & - \\
\hline \multirow[t]{2}{*}{3,704} & $\mathrm{C}$ & $\mathrm{U}$ & p31 & Ala & Val \\
\hline & & & $\mathrm{CP}$ & - & - \\
\hline 3,929 & $\mathrm{C}$ & $\mathrm{U}$ & $\mathrm{CP}$ & - & - \\
\hline 4,095 & G & A & $3^{\prime}$-NTR & $\mathrm{NA}^{\mathrm{d}}$ & $\mathrm{NA}^{\mathrm{d}}$ \\
\hline 4,406 & G & Indel $^{\mathrm{a}}$ & $3^{\prime}$-NTR & $\mathrm{NA}^{\mathrm{d}}$ & $\mathrm{NA}^{\mathrm{d}}$ \\
\hline
\end{tabular}

a Polymorphism due to insertion or deletion (Indel) of one nucleotide

b Dash (-) denotes synonymous substitution not affecting encoded protein

c Amino acid change due to combined effect of substitutions at nts 488 and 489

d Not applicable as polymorphism present in $3^{\prime}$-nontranslated region (3'-NTR)

assemblage, the $5^{\prime}$-terminus was fused to a $\mathrm{T} 7$ promoter and the $3^{\prime}$-terminus (CCC) was positioned immediately upstream of GGG to generate a Sma I site. Internal sequences were selected from various cDNA clones such that all nucleotide positions were identical to the consensus sequence reported for MCMV-NE. Two plasmids bearing the full-length consensus sequence of MCMV-NE were linearized with Sma I and used as template for in vitro transcription with T7 RNA polymerase as described [1]. In vitro transcribed MCMV-NE RNA was mechanically inoculated to SDp2 maize seedlings. Capped transcripts from both plasmid templates were infectious; $4 / 6$ and $6 / 6$ plants displayed mild systemic chlorotic mottling of leaves by two weeks post-inoculation. RT-PCR of the MCMV-NE $\mathrm{CP}$ coding region [8] was used to verify infection status of transcript-inoculated plants. Symptomatic plants yielded RT-PCR products of the expected size (673 bp), whereas no RT-PCR product was amplified from asymptomatic inoculated plants or uninoculated plants serving as negative controls. Progeny virus derived from MCMV-NE-transcript-inoculated plants was competent to produce CLND upon co-inoculation of SDp2 maize plants with WSMV. As RNA transcribed from the cloned consensus sequence of MCMV-NE was infectious to plants and produced disease phenotypes similar to MCMV-KS in both single infections and in mixed infections with WSMV, the limited sequence differences between MCMV-NE and MCMV-KS are most likely neutral with respect to pathogenicity and virulence.

Acknowledgments We thank Brock A. Young for technical assistance. Mention of proprietary or brand names is necessary to report factually on available data; however, the USDA neither guarantees nor warrants the standard of the product, and the use of the name by USDA implies no approval to the exclusion of others that also may be suitable. This article is in the public domain and not copyrightable. It may be freely reprinted with customary crediting of source.

\section{References}

1. Choi I-R, French R, Hein GL, Stenger DC (1999) Fully biologically active in vitro transcripts of the eriophyid mitetransmitted wheat streak mosaic tritimovirus. Phytopathology 89:1182-1185

2. Goldberg KA, Brakke MK (1987) Concentration of maize chlorotic mottle virus in mixed infections with maize dwarf mosaic virus, strain B. Phytopathology 77:162-177

3. Lommel SA, Kendall TL, Siu NF, Nutter RC (1991) Characterization of maize chlorotic mottle virus. Phytopathology 81:819823

4. Niblett CL, Clafin LE (1978) Corn lethal necrosis-a new virus disease of corn in Kansas. Plant Dis Report 62:15-19

5. Nutter RC, Scheets K, Pangnaniban LC, Lommel SA (1989) The complete nucleotide sequence of the maize chlorotic mottle virus genome. Nucleic Acids Res 17:3163-3177

6. Scheets K (1998) Maize chlorotic mottle machlomovirus and wheat streak mosaic rymovirus concentrations increase in the synergistic disease corn lethal necrosis. Virology 242:28-38

7. Scheets K, Khosravifar R, Nutter RC (1993) Transcripts of a maize chlorotic mottle virus cDNA clone replicate in maize protoplasts and infect maize plants. Virology 193:1006-1009

8. Stenger DC, Young BA, Qu F, Morris TJ, French R (2007) Wheat streak mosaic virus lacking helper component-proteinase is competent to produce disease synergism in double infections with Maize chlorotic mottle virus. Phytopathology 97:1213-1221

9. Uyemoto JK (1983) Biology and control of maize chlorotic mottle virus. Plant Dis 67:7-10 